\title{
TŁUMACZENIE Z JĘZYKA POLSKIEGO NA JĘZYK FRANCUSKI W DOCHODZENIU ROSZCZEŃ ALIMENTACYJNYCH ZA GRANICA: SŁOWNIKI DWUJĘZYCZNE I TEKSTY PARALELNE W PRACY TŁUMACZA
}

DOl: http://dx.doi.org/10.12775/RP.2015.005

Zarys treści: Autor porusza problematykę tłumaczenia poświadczonego w dochodzeniu roszczeń alimentacyjnych za granicą z punktu widzenia tłumacza. Najpierw przedstawia funkcję i przedmiot tłumaczenia, a następnie wyjaśnia na przykładach z własnej praktyki translatorskiej, dlaczego odpowiednie teksty paralelne są obecnie lepszym narzędziem pracy od polsko-francuskich słowników terminologii prawniczej.

Słowa kluczowe: tłumaczenie poświadczone, roszczenie alimentacyjne, teksty paralelne

\section{Wprowadzenie}

N aszym celem jest przedstawienie przydatności dwóch rodzajów narzędzi translatorskich w pozyskiwaniu informacji potrzebnych do wykonania tłumaczenia poświadczonego na zlecenie sądu okręgowego w związku z dochodzeniem roszczeń alimentacyjnych od osób zamieszkałych we Francji: współczesnych polsko-francuskich słowników terminologii prawniczej i tekstów paralelnych, jakimi są polsko- i francuskojęzyczna wersja umowy międzynarodowej stanowiącej podstawę prawną postępowania.

W pracy tłumacza przysięgłego międzynarodowe regulacje prawne traktujemy jako narzędzie umożliwiające dostęp do środków językowych zapre- 
zentowanych w mniej tradycyjny sposób, niż czynią to porównywane z nimi słowniki. W przeciwieństwie do tych ostatnich różne wersje językowe aktów prawnych, po pierwsze, przedstawiają zasoby językowe w szerokim kontekście językowym, a po drugie, bardzo wyraźnie wskazują potencjalne użycie środków językowych, czyli ich kontekst pozajęzykowy. Ale czy to jest wystarczający powód, by uznać je za bardziej przydatne od słowników dwujęzycznych?

Ponieważ skuteczność narzędzi rozpatrzymy pod kątem możliwości wykorzystania ich przez tłumacza, w pierwszej kolejności przedstawimy główne cechy tłumaczenia $w$ dochodzeniu roszczeń alimentacyjnych za granicą (p. 1). Z konieczności skupimy się na najczęściej tłumaczonym dokumencie postępowania, tzw. piśmie przewodnim polskiego sądu, a w szczególności na kontekście społeczno-kulturowym tego pisma. Stanowi on płaszczyznę porównania obu rodzajów narzędzi, które nastąpi w dalszej kolejności (p. 3), po przedstawieniu przykładów narzędzi translacyjnych, jakie mogą być wykorzystywane w przekładzie przedmiotowej korespondencji (p. 2).

\section{Wyróżniki tłumaczenia w dochodzeniu roszczeń alimentacyjnych za granicą}

\subsection{Funkcja tłumaczenia}

Biorąc pod uwagę funkcję tłumaczenia i okoliczności, w jakich jest praktykowane, Sylvie Monjean-Decaudin wymienia cztery konteksty tłumaczenia prawniczego. Jednym z nich jest "kontekst sądowy”, w którym tłumaczenie pełni dwie funkcje: jest narzędziem komunikacji w obrocie prawnym z zagranicą oraz umożliwia organom wymiaru sprawiedliwości przeprowadzenie postępowania, którego uczestnikiem jest cudzoziemiec (Monjean-Decaudin 2010: 2-4) ${ }^{1}$. Tłumaczenie będące przedmiotem artykułu pełni pierwszą z wymienionych funkcji, służąc polskiemu sądowi okręgowemu w komunikowaniu się z francuskim Ministerstwem Spraw Zagranicznych w Paryżu w toku postępowania mającego na celu uzyskanie, zasądzonych wyrokiem lub ustalonych ugodą sądową, świadczeń alimentacyjnych od osoby zobowiązanej do

1 Trzy pozostałe konteksty to: 1) „kontekst prawa międzynarodowego publicznego” (tłumaczenie służy tworzeniu prawa $w$ ramach organizacji i instytucji międzynarodowych, np. jednakowa moc prawna traktatów we wszystkich językach urzędowych UE), 2) „kontekst prawa międzynarodowego prywatnego" (tłumaczenie na potrzeby osób fizycznych i prawnych w celu egzekwowania prawa, np. dokumentów USC, aktów notarialnych), 3) „kontekst naukowy” (np. tłumaczenie aktów normatywnych na użytek komparatystyki prawniczej). 
alimentacji znajdującej się pod jurysdykcją francuskiego wymiaru sprawiedliwości na rzecz osoby uprawnionej do alimentacji zamieszkałej w Polsce².

\subsection{Różnorodność przedmiotu tłumaczenia}

Naszym zdaniem specyfika tłumaczenia $\mathrm{w}$ kontekście sądowym polega przede wszystkim na jego różnorodności. W przypadku dochodzenia roszczeń alimentacyjnych za granicą przedmiotem tłumaczenia mogą być bowiem dokumenty, które:

1) uprawniony lub jego ustawowy przedstawiciel sam dostarczył sądowi, np. wniosek uprawnionego w sprawie uzyskania świadczeń alimentacyjnych, wykaz zaległości alimentacyjnych, pełnomocnictwo upoważniające organ zagraniczny do podjęcia czynności właściwych dla uzyskania alimentów, informacja o koncie bankowym, odpisy aktów ślubu i urodzenia, zaświadczenia o odbywaniu nauki, o miejscu zamieszkania, a w razie potrzeby również dokumenty wymagane przy staraniu się o pomoc prawną (np. deklaracja podatkowa);

2) polski sąd i francuskie ministerstwo sporządziły w toku postępowania, jak pisma sądu do strony francuskiej i odpowiedzi na nie, protokół z przesłuchania osoby zobowiązanej, opinia sądu dotycząca merytorycznych podstaw wniosku uprawnionego, zaświadczenie o niewniesieniu apelacji;

3) polskie sądy - rejonowy i okręgowy - wydały w toku spraw o rozwód, zasądzenie lub zmianę wysokości alimentów: wyrok, wezwanie do stawienia się w sądzie wraz z pouczeniem o treści stosownych artykułów kodeksu postępowania cywilnego, wyciąg z protokołu ugody.

Dokumenty te cechuje duże zróżnicowanie gatunkowe, ponieważ różnią się we wszystkich wymiarach przyjętych jako wyznaczniki wzorca gatunkowego: pragmatycznym (sytuacja nadawczo-odbiorcza, funkcja komunikatu), struktury (rama tekstowa, kolejność segmentów), poznawczym (przedmiot pisma) i stylistycznym (środki językowe) (Wojtak 2005: 138). Jeżeli zestawimy wymienione powyżej dokumenty z kategoryzacją tekstów sfery prawa zaproponowaną przez Stanisława Gajdę (2004: 28), okaże się, że pięć z ośmiu

${ }^{2}$ Dochodzenie roszczeń alimentacyjnych od osób zobowiązanych zamieszkałych za granicą należy do czynności sądu z zakresu międzynarodowego postępowania cywilnego (Ciszewski 2010: 25-29). Oprócz spraw cywilnych tłumaczenie pisemne w „kontekście sądowym” wykonywane jest również na potrzeby spraw karnych. 
wymienionych na liście Gajdy gatunków ma swoje odpowiedniki pośród załączników pisma sądu okręgowego do MSZ Francji. Są nimi: tekst o charakterze normatywnym (pouczenie), tekst sądowy (np. wyrok), tekst wyrażający roszczenia prawne (np. wniosek uprawnionego), tekst związany z egzekwowaniem prawa (ugoda), teksty będące urzędowym potwierdzeniem (zaświad(zenia) $)^{3}$.

Ponieważ nie sposób jednym artykułem objąć całej różnorodności tekstów, w dalszej części ograniczymy przedmiot naszego zainteresowania do najczęściej tłumaczonego dokumentu w tym postępowaniu, jakim jest pismo sądu okręgowego do MSZ Francji, nazywane przez personel sądu pismem przewodnim.

\subsection{Cechy pisma przewodniego}

Pismo przewodnie pełni funkcję zgodną ze znaczeniem przymiotnika „przewodni”: „główny, podstawowy, zasadniczy, wytyczający kierunek działań, dążeń" (Dunaj 1996: 897). Pismo przewodnie jest więc najważniejszym elementem korespondencji sądu okręgowego z organem francuskim, do którego zazwyczaj załączane są inne dokumenty. Jego głównymi cechami są eksplicytność i konwencjonalność.

Pierwsza cecha odzwierciedla przyjętą w sferze prawa zasadę eksplicytności tekstu prawnego, która oznacza, że znaczenie nie wynika z sytuacji komunikacji, ale bezpośrednio z użytych środków językowych (Jopek 2001: 86). Nie ma w tym przypadku miejsca na jakieś dodatkowe implikacje znaczeniowe różne od tych, które dopuszcza wykładnia prawa. Znaczenie określonego przepisu prawnego jest przypisane do tekstu tego przepisu do momentu, aż zostanie zmienione innym przepisem.

Naszym zdaniem tę zasadę można odnieść również do przedmiotowej korespondencji, choć ta $\mathrm{w}$ większości do tekstów prawnych się nie zalicza ${ }^{4}$. Znaczenie pisma przewodniego, podobnie jak znaczenie przepisu prawnego, nie zmienia się wraz ze zmianą sytuacji komunikacji; nie jest ważne, który z 45 polskich sądów okręgowych prowadzi korespondencję z francuskim mi-

${ }^{3}$ Trzy gatunki tekstowe wymienione przez Gajdę, które nie występują w dochodzeniu roszczeń alimentacyjnych, to: teksty komentujące teksty normatywne (np. wykładnia), teksty stanowiące wyraz umowy (np. statut) oraz naukowe i dydaktyczne teksty poznawcze (np. artykuł, podręcznik).

${ }^{4}$ Tylko będące fragmentem Kodeksu postępowania cywilnego pouczenie należy do sfery stanowienia prawa, pozostałe zaś teksty korespondencji są ze sfery stosowania prawa. 
nisterstwem, ale to, w jakiej sprawie, a o tym informują użyte środki językowe. Wszelkie implikacje znaczenia uregulowane są bądź ogólnymi zasadami interpretacji tekstów prawnych, bądź podstawą prawną postępowania.

Z kolei idea konwencjonalności komunikatu ma swoje źródło w bachtinowskiej koncepcji gatunków mowy, według której zachowania językowe mają charakter schematyczny, tzn. powtarzalny (Wojtak 2004: 13). Ta koncepcja zbieżna jest w sposobie patrzenia na wypowiedź z tym, co określa się jako skonwencjonalizowany charakter tekstu ${ }^{5}$. Praktyka translatorska pokazuje, że pismo przewodnie jest pisane w sposób schematyczny. Jednakże tylko pismo rozpoczynające korespondencję, w którym sąd powiela Wzór pisma organu przesyłającego w sprawie przekazania organowi przyjmującemu wniosku osoby uprawnionej ${ }^{6}$, należałoby uznać za tekst w pełni skonwencjonalizowany. Każde następne pismo sądu okręgowego w tej samej sprawie różni się od poprzedniego niektórymi elementami treści, w zależności od biegu sprawy, które jednak są przewidywalne. Dlatego w ich przypadku możemy mówić o mniejszym stopniu skonwencjonalizowania lub o tekstach „częściowo skonwencjonalizowanych" (Wilkoń 2002: 201-204).

\subsection{Kontekst społeczno-kulturowy pisma przewodniego}

Jak to pokazujemy na schemacie zamieszczonym poniżej, kontekst społeczny pisma przewodniego stanowią uczestnicy nie jednej, lecz czterech wzajemnie oddziałujących na siebie sytuacji nadawczo-odbiorczych: głównej i trzech pobocznych? . W głównej sytuacji nadawczo-odbiorczej uczestniczą polski sąd okręgowy (SO) i MSZ Francji (MSZ), grając na zmianę rolę nadawcy i odbiorcy w prowadzonej przez kilka lat korespondencji. Przemienność ról charakterystyczna jest również dla trzech pobocznych sytuacji nadawczo-odbiorczych, których uczestnikami są: 1) uprawniony do alimentacji (U) i sąd

${ }^{5}$ Według Reginy Solovej tekstami skonwencjonalizowanymi są formy „o spetryfikowanej strukturze, mające określony porządek występowania poszczególnych sekwencji, stałe elementy treści, stereotypową realizację językową oraz określoną funkcję, zdeterminowaną daną sytuacją komunikacyjną" (Solovà 2009: 202).

${ }^{6}$ Załącznik nr 20 do Rozporządzenia Ministra Sprawiedliwości z dnia 28 stycznia 2002 r. w sprawie szczegółowych czynności sądów z zakresu międzynarodowego postępowania cywilnego oraz karnego w stosunkach międzynarodowych. Tekst dostępny na http://isap.sejm.gov.pl/. (dostęp: 17 października 2013 r.).

${ }^{7} \mathrm{O}$ oddziaływaniu pobocznych sytuacji nadawczo-odbiorczych na główną napisaliśmy w artykule z 2013. 
okręgowy (SO), 2) sąd okręgowy (SO) i tłumacz (T), 3) MSZ Francji (MSZ) i zobowiązany do alimentacji $(\mathrm{Z})^{8}$.

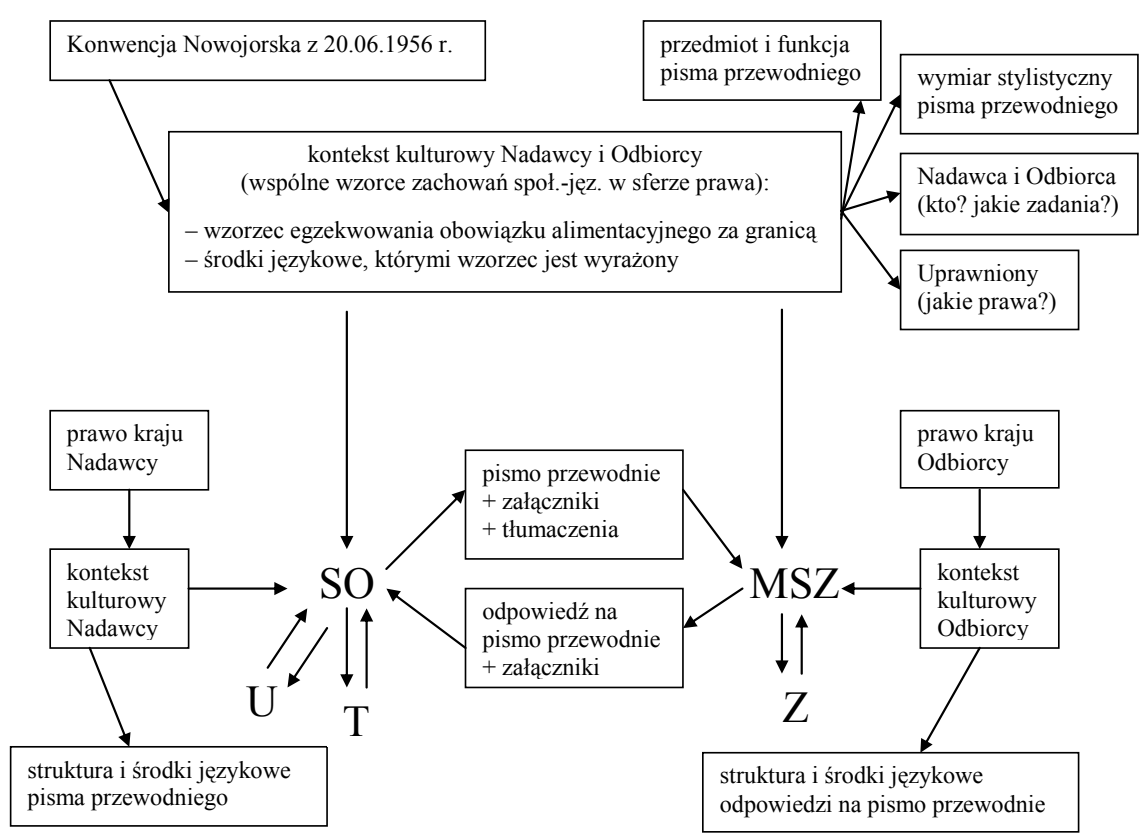

Kontekst społeczno-kulturowy pisma przewodniego ${ }^{9}$

Warunkiem rozpoczęcia korespondencji sądu okręgowego z MSZ Francji jest złożenie w sądzie wniosku osoby uprawnionej w sprawie uzyskania świadczeń alimentacyjnych. Sąd może zwrócić się do uprawnionego o uzupełnienie wniosku natychmiast lub po otrzymaniu odpowiedzi z MSZ Francji. Następnie sąd zleca tłumaczenie pisma przewodniego wraz z załącznikami, a po wykonaniu zadania przez tłumacza przesyła dokumenty do MSZ Francji, które z kolei zwraca się do zobowiązanego, by po uzyskaniu od niego wyjaśnień odpowiedzieć na pismo sądu okręgowego. Sąd przesyła tę odpowiedź do tłumacza, tego samego co poprzednio albo innego, wybranego z listy tłumaczy przysięgłych, po czym formułuje kolejne pismo do MSZ Francji,

8 „Uprawniony” i „zobowiązany” są w tym postępowaniu synonimami „wierzyciela” $\mathrm{i}$ „dłużnika”, por. przyp. 15.

${ }^{9}$ Dotyczy dochodzenia roszczeń alimentacyjnych za granicą $\mathrm{w}$ trybie Konwencji Nowojorskiej z 20.06.1956 r. 
jeśli postępowanie jest kontynuowane. Zdarza się, że w dalszym toku postępowania sąd pomija etap tłumaczenia poświadczonego. Wówczas to personel sądu tłumaczy pismo przewodnie lub odpowiedź na nie.

Przez kontekst kulturowy pisma przewodniego rozumiemy wzorce zachowań społeczno-językowych, które określona wspólnota kulturowo-językowa wykształciła w sferze prawa ${ }^{10}$. Chodzi o, jak to ujmują prawnicy, określony „wzorzec rozstrzygania problemów społecznych” (Zieliński 2004: 10), a także o środki językowe, którymi wzorzec zachowania jest wyrażony. W przedmiotowym postępowaniu tym wzorcem jest sposób egzekwowania obowiązku alimentacyjnego na rzecz osoby uprawnionej do alimentacji. Jego źródłami są regulacje prawne na poziomie krajowym i międzynarodowym. Z naszych obserwacji wynika, że kontekst kulturowy nadawcy, którego częścią jest prawo kraju nadawcy, odpowiada za strukturę i środki językowe pisma przewodniego ${ }^{11}$, podobnie jak kontekst kulturowy odbiorcy wpływa na strukturę i środki językowe odpowiedzi na pismo przewodnie. Natomiast za pozostałe wyznaczniki pisma przewodniego odpowiedzialny jest wspólny kontekst kulturowy nadawcy i odbiorcy. W okresie, z którego pochodzą cytowane przez nas przykłady, roszczenia alimentacyjne od osób zobowiązanych zamieszkałych we Francji na rzecz osób uprawnionych zamieszkałych w Polsce były prowadzone na podstawie Konwencji Nowojorskiej z 20 czerwca 1956 r. o dochodzeniu roszczeń alimentacyjnych za granicą (odtąd Konwencja Nowojorska). Ta umowa międzynarodowa, którą Polska i Francja ratyfikowały w 1960 r., tworzy wspólny kontekst kulturowy nadawcy i odbiorcy pisma przewodniego. Kontekst ten stanowi o tym, kto może być nadawcą i odbiorcą, wyznacza ich kompetencje oraz prawa uprawnionego, a także określa przedmiot i funkcję pisma. Ma również wpływ na jego wymiar stylistyczny: spośród środków językowych, którymi wzorzec dochodzenia roszczeń alimentacyjnych został wyrażony w polskiej wersji językowej Konwencji Nowojorskiej, pochodzą charakterystyczne dla pisma przewodniego terminy i związki frazeologiczne. Należy wszakże pamiętać, że środki te należą do kontekstu kulturowego nadawcy, podobnie jak środki językowe użyte w wersji francuskojęzycznej Konwencji Nowojorskiej należą do kontekstu kulturowego odbiorcy pisma przewodniego ${ }^{12}$.

${ }^{10}$ Używamy określenia „sfera prawa” w odniesieniu do jednej ze „sfer kulturowych”, wydzielonych „ze względu na dominujący typ świadomości oraz zachowań” (Gajda 2004: 21).

${ }^{11}$ Ważną rolę w tym względzie odgrywa przywoływany już zał. nr 20 do Rozporządzenia Ministra Sprawiedliwości z dnia 28 stycznia 2002 r.

12 Taka sytuacja powoduje, że podstawowa trudność w tłumaczeniu prawniczym związana z tym, co Marie Cornu (2011) nazywa „ładunkiem znaczeniowym określonego pojęcia” („char- 
Oto kilka zasad regulujących egzekwowanie obowiązku alimentacyjnego sformułowanych w Konwencji Nowojorskiej. Na przykład w artykule 3 zostało zapisane, że uprawniony może złożyć do organu nazwanego „Organem przesyłającym” w państwie swego zamieszkania wniosek, w którym domaga się od zobowiązanego uiszczania okresowych świadczeń pieniężnych. Z kolei artykuł 4 stanowi, że Organ przesyłający, jeśli uzna wniosek uprawnionego za uzasadniony, przekazuje wymaganą dokumentację do „Organu przyjmującego" w państwie zobowiązanego, dołączając ewentualnie swoją opinię w sprawie uzasadnienia wniosku uprawnionego, jak również może zalecić przyznanie uprawnionemu bezpłatnej ochrony prawnej i zwolnienie od kosztów. Następnie artykuł 6 określa dwa obowiązki Organu przyjmującego: 1) podjęcie w ramach udzielonego mu przez uprawnionego upoważnienia i w jego zastępstwie wszelkich czynności właściwych do uzyskania alimentów, włącznie $\mathrm{z}$ uregulowaniem roszczenia $\mathrm{w}$ drodze ugody $\mathrm{i}, \mathrm{w}$ razie potrzeby, do wszczęcia i prowadzenia sprawy z powództwa o alimenty oraz przeprowadzenia egzekucji z wyroku albo jakiegokolwiek innego tytułu sądowego zasądzającego alimenty; 2) informowanie Organu przesyłającego o biegu sprawy, a jeżeli nie może nadać biegu sprawie, zawiadomienie Organu przesyłającego o przyczynach i zwrócenie akt.

W Polsce funkcję Organu przesyłającego pełnią sądy okręgowe. W sądzie, z którego pochodzą omawiane przykłady, obrotem prawnym z zagranicą zajmuje się wydział wizytacyjny. Pisma przewodnie podpisuje prezes, ewentualnie upoważnieni pracownicy sądu na stanowiskach: sędziego wizytatora ds. obrotu prawnego z zagranicą i prawa wspólnotowego, starszego sekretarza sądowego, sekretarza lub specjalisty.

Organem przyjmującym jest, według obecnie obowiązującej nazwy, Ministerstwo Spraw Zagranicznych (Ministère des Affaires Étrangères) w Paryżu. Odpowiedzi na pisma przewodnie polskiego sądu okręgowego redagują urzędnicy Biura ds. Dochodzenia Roszczeń Alimentacyjnych za Granicą (Bureau du recouvrement des créances alimentaires à létranger), a podpisuje je przeważnie kierownik biura (Chef de Bureau).

ge conceptuelle d'une notion"), nie jest już dla tłumacza aż tak dotkliwa jak w sytuacji, kiedy dziedzina, której dotyczy tłumaczony tekst, nie była przedmiotem międzynarodowych regulacji prawnych, ponieważ problem zgodności pojęć między językiem źródłowym i docelowym został rozwiązany przez autorów różnych wersji językowych aktu prawnego. Ponadto, ukazując językowy kontekst użycia określonych terminów, tego rodzaju teksty paralelne łagodzą równocześnie inny rodzaj problemów tłumaczeniowych, jakim jest frazeologia języka prawniczego. 


\section{Narzędzia pracy tłumacza w przekładzie korespondencji na użytek dochodzenia roszczeń alimentacyjnych za granicą}

$\mathrm{Z}$ aktualnie dostępnych na rynku polsko-francuskich słowników terminologii prawniczej weźmiemy pod uwagę trzy tytuły, które wymieniamy według kolejności wydania:

- Polsko-francuski słownik terminologii prawniczej/Dictionnaire polonais-français des termes juridiques Ewy Łozińskiej-Małkiewicz z 2003 r.,

- Słownik terminologii prawniczej francusko-polski polsko-francuski Marty T. Bem i Małgorzaty Gebler z 2011 r.,

- Słownik terminologii prawniczej polsko-francuski/Dictionnaire de la terminologie juridique polonais-français Aleksandry Machowskiej z $2013 \mathrm{r}$.

Przydatność wyżej wymienionych słowników porównamy z możliwościami, jakie stwarzają polsko- i francuskojęzyczny tekst Konwencji Nowojorskiej. Wersję w języku polskim udostępniają sądy okręgowe na swoich stronach internetowych (np. http://www. warszawa.so.gov.pl/panstwa konwencji-nowojorskiej-z-20061956r.html). Z kolei tekst w języku francuskim zamieszcza Sekretariat ONZ (http://treaties.un.org/doc/Publication/UNTS/ Volume\%20268/volume-268-I-3850French.pdf).

Trzeba jednak pamiętać, że postępowania, które obecnie są wszczynane $\mathrm{w}$ zakresie zobowiązań alimentacyjnych $\mathrm{w}$ obrocie prawnym $\mathrm{z}$ Francją, mają już za podstawę prawną akty prawa Unii Europejskiej. Dlatego w ich przypadku warto skorzystać np. ze strony http://europa.eu/legislation_summaries/justice_freedom_security/ enlargement/index_fr.htm (tytuły linków: 1) Justice, liberté et sécurité, 2) Coopération judiciaire en matière civile i 3) Obligations alimentaires ${ }^{13}$, na której widnieją akty prawne przyjęte przez Wspólnotę w latach 2001-2009 w celu uproszczenia i przyspieszenia postępowań dotyczących wierzytelności alimentacyjnych. Teksty dostępne są w widoku dwujęzycznym, co znacznie ułatwia odszukanie odpowiednich segmentów. Obecnie w większości państw członkowskich Unii Europejskiej stosowane jest Rozporządzenie Rady (WE) nr 4/2009 z 18 grudnia 2008 r. w sprawie jurysdykcji, prawa właściwego, uznawania i wykonywania orzeczeń oraz współpracy w zakresie zobowiązań alimentacyjnych oraz Protokół o prawie właściwym dla zobowiązań alimentacyjnych sporządzony w Hadze dnia 23.11.2007 r.

${ }^{13}$ Dostęp do wszystkich aktów prawa UE zapewnia poza tym strona http://eur-lex.europa.eu. 
Równie cennym źródłem informacji dla tłumacza są formularze umieszczane w załącznikach do aktów prawnych Unii Europejskiej. Na przykład Zaświadczenie zgodne z art. 54 i 58 rozporządzenia dotyczące orzeczeń sądowych i ugód sądowych jest załączone do Rozporządzenia Rady (WE) nr 4/2009, a Formularz wniosku o prawo pomocy w innym państwie członkowskim Unii Europejskiej - do Rozporządzenia Rady (WE) nr 44/2001 z dnia 22 grudnia 2000 r. w sprawie jurysdykcji i uznawania orzeczeń sądowych oraz ich wykonywania w sprawach cywilnych i handlowych. Tłumaczenie jednego lub drugiego formularza byłoby trudnym zadaniem dla kogoś, kto nie ma odpowiednich kompetencji językowych i wiedzy z dziedziny prawa. Wielojęzyczne formularze pozwalają tłumaczowi wywiązać się z zadania w sytuacji, kiedy sąd wydaje się nie wiedzieć o ich istnieniu i zleca tłumaczenie wpisów do formularza razem $\mathrm{z}$ tłumaczeniem tekstu stałego.

Ponadto jest kilka internetowych źródeł informacji o aktualnie używanych zasobach językowych w zakresie międzynarodowego obrotu prawnego na obszarze UE. Przedstawiamy dwa z nich, do których warto zaglądać, wykonując tłumaczenie na zlecenie sądu. Pierwszym jest IATE (InterActive Terminology for Europe). Ta Wielojęzyczna baza terminologiczna, z której korzystają służby tłumaczeniowe instytucji wspólnotowych, dostępna na stronie http://www.iate.europa.eu, pozwala odszukać termin lub fragment zdania ze wszystkich dziedzin działalności UE. Zawiera propozycje tłumaczeń danego terminu na wiele języków urzędowych, choć nie zawsze na wszystkie. Jest na bieżąco uzupełniana, również przez tłumaczy, którzy mają możliwość wprowadzania nowych ekwiwalentów tłumaczeniowych bądź uzupełniania istniejących definicji. W artykułach hasłowych znajdziemy definicje terminów, przykłady ich użycia, komentarze oraz odniesienia do tekstów źródłowych.

Drugim źródłem jest Europejski Atlas Sądowniczy na stronie Komisji Europejskiej (http://ec.europa.eu/justice_home/judicialatlascivil/html/index_ pl.htm) zawierający informacje na temat współpracy sądowej w sprawach cywilnych pogrupowane $\mathrm{w}$ dziewięciu kategoriach tematycznych: „Sądy w państwach członkowskich”, „Pomoc prawna”, „Mediacja”, „Doręczenie dokumentów”, „Europejskie procedury transgraniczne”, „Przeprowadzanie dowodu”, „Uznawanie i wykonywanie orzeczeń”, „Prawo rodzinne” (w tym zobowiązania alimentacyjne), „Kompensata dla ofiar przestępstw”. Dla tłumacza sądowego jest to kolejne bardzo użyteczne źródło tekstów paralelnych. 


\section{Terminologiczno-frazeologiczne aspekty tłumaczenia pisma prze- wodniego na język francuski}

Przedstawienie problemów tłumaczeniowych towarzyszących dochodzeniu roszczeń alimentacyjnych za granicą zawężamy do sprawy wyboru przez tłumacza ekwiwalentów w języku francuskim kilku najbardziej charakterystycznych terminów i kolokacji pisma przewodniego, których źródłem jest zaprezentowany powyżej kontekst społeczno-kulturowy. Inne terminy i kolokacje, nie mniej interesujące, lecz związane $\mathrm{z}$ innymi uwarunkowaniami, zostaną z konieczności pominięte. Przykłady pochodzącą z akt sześciu spraw prowadzonych przez jeden z 45 sądów okręgowych w latach 2000-2010.

Przedmiot pisma przewodniego sformułowany jest w następujący sposób:

Dotyczy: Realizacji roszczeń o alimenty na podstawie Konwencji o dochodzeniu roszczeń alimentacyjnych za granicą sporządzonej w Nowym Jorku dnia 20 czerwca 1956 roku.

W zakresie dwóch kolokacji „realizacja roszczeń o alimenty” i „dochodzenie roszczeń alimentacyjnych" trzy specjalistyczne słowniki proponują następujące ekwiwalenty w języku francuskim: 1) "alimentacyjny - alimentaire, d’alimentation”, „roszczenie o alimenty - prétention en aliments”, „dochodzenie roszczen - poursuite des prétentions”, „realizacja - réalisation”, „roszczenie alimentacyjne - prétention alimentaire" (Łozińska-Małkiewicz 2003: $11,74,543,558)$; 2) „alimenty - aliments, pension”, „realizacja - réalisation”, „roszczenie - prétention, revendication, intérêt” (Bem, Gebler 2011: 153, 252, 255); 3) „alimentacyjny - alimentaire”, ,alimenty - aliments, pension alimentaire”, „dochodzenie - poursuite, enquête”, „realizacja - réalisation, exécution, mise en oeuvre" (Machowska 2013: 32, 94, 492). W naszym przekonaniu zadanie jest niewykonalne przy użyciu wyżej wymienionych środków językowych. Terminy „poursuite”, „prétention”, „revendication” odnoszą się do postępowań procesowych, podczas gdy w tym przypadku chodzi o postępowanie nieprocesowe, ponieważ alimenty zostały już wcześniej zasądzone wyrokiem lub ustalone ugodą przed sądem. Poprawne rozwiązanie tego problemu tłumaczeniowego możliwe jest przede wszystkim dzięki Konwencji Nowojorskiej, której francuskojęzyczny tytuł zawiera ekwiwalent kolokacji „dochodzenie roszczeń alimentacyjnych”: „recouvrement des aliments”. Odnośnie do „realizacji roszczeń o alimenty” możliwe są dwa rozwiązania. Po pierwsze „dochodzenie roszczeń alimentacyjnych, i „realizacja roszczeń o alimenty" są w tym przypadku określeniami synonimicznymi, oznaczają- 
cymi sytuację, w której uprawniony żąda od zobowiązanego spełnienia obowiązku alimentacyjnego. Wynika z tego, że również ekwiwalentem „realizacji roszczeń o alimenty” może być tytułowe „recouvrement des aliments”. Inną możliwość podpowiada MSZ w Paryżu, które w jednej z odpowiedzi do sądu okręgowego użyło sformułowania „le dossier de recouvrement de la créance alimentaire de Madame...”, co pozwala przyjąć, że ekwiwalentem tej samej kolokacji może być także „recouvrement de la créance alimentaire”.

Kolejny przykład dotyczy nazwy używanej na określenie odbiorcy pisma przewodniego. Tylko jeden słownik podaje ekwiwalent kolokacji „organ przyjmujący”: „autorité destinataire”, który różni się jednak od terminu użytego we francuskojęzycznej wersji Konwencji Nowojorskiej: „institution intermédiaire"14. Ten sam słownik wyodrębnia hasło "przyjmujący - recevant” (Łozińska-Małkiewicz 2003: 368, 528). Dwa pozostałe słowniki podają czasowniki: „przyjmować - recevoir” (Bem, Gebler 2011:248) i „przyjąć - recevoir, accepter, adopter, admettre" (Machowska 2013: 478). Użycie w tłumaczeniu ekwiwalentu ze słownika nie powinno zakłócić komunikacji, ale pismo przewodnie jest, jak to wyżej stwierdziliśmy, pismem oficjalnym; w dodatku została ustalona określona norma dotycząca także użycia w określonej sytuacji określonych środków językowych, a to naszym zdaniem powinno mieć swoje konsekwencje w takim samym stopniu dla sądu jak i dla tłumacza.

W przypadku kolokacji „organ przesyłający” słowniki proponują nieco więcej środków: 1) „organ/y - organe”, „wysyłający - expéditeur” (Łozińska-Małkiewicz 2003: 367, 836); 2) „organ - organe, autorité, instance, institution”, „wysyłający - expéditeur (-trice) (Bem, Gebler 2011: 221, 299); 3) „organ przesyłający - organe expéditeur; institution expéditrice, autorité expéditrice" (Machowska 2013: 345). Jednakże ze słowników tłumacz się nie dowie, że ekwiwalent, o który w tym przypadku chodzi, to „autorité expéditrice”.

Zdarzają się sytuacje, kiedy sąd nie stosuje terminologii Konwencji Nowojorskiej, jak to jest w przypadku terminu „uprawniony”, np. w kolokacjach „wniosek wierzycielki alimentacyjnej”, „wniosek osoby uprawnionej”. Z kolei zamiast terminu „zobowiązany” konsekwentnie używany jest termin „dłużnik”, np. „lekceważący stosunek dłużnika”, „dłużnik alimentacyjny”. W tym przypadku niezgodność terminologiczna jest tylko pozorna, ponieważ ekwiwalentami

${ }^{14}$ Jeśli nie „institution intermédiaire”, to w tłumaczeniu należałoby raczej użyć określenia „autorité réceptrice”, jakim np. MSZ w Paryżu nazywa swoje Biuro ds. Międzynarodowej Współpracy w sprawach Cywilnych i Handlowych, kiedy zaleca uprawnionemu zwrócenie się o pomoc prawną. To określenie jest zresztą powszechnie stosowane w odniesieniu do organu właściwego do przyjmowania dokumentów. 
terminów „uprawniony” i „zobowiązany” są we francuskiej wersji Konwencji Nowojorskiej „créancier” i „débiteur”, czyli te same terminy, które w języku francuskim odpowiadają polskim terminom „wierzyciel” i „dłużnik”, co oznacza, że „uprawniony” i „wierzyciel” są tutaj synonimiczne, a sąd używa ich zamiennie. Podobnie należy potraktować terminy „zobowiązany” i „dłużnik”"15.

Wszystkie trzy słowniki podają „débiteur” i „créancier” jako ekwiwalenty terminów „dłużnik” i „wierzyciel”, ale tylko jeden wymienia kolokację „dłużnik alimentacyjny”, której odpowiada „débiteur d’aliments” (Machowska 2013: 92), i żaden z trzech słowników nie uwzględnia kolokacji „wierzyciel alimentacyjny".

Jeśli chodzi o „wniosek osoby uprawnionej”, w świetle Konwencji Nowojorskiej tłumaczenie w tym przypadku powinno brzmieć „demande du créancier". Tymczasem żaden z trzech słowników nie odnotowuje tej kolokacji w całości, lecz tylko jej poszczególne elementy. Termin „wniosek” figuruje jako odrębne hasło we wszystkich trzech słownikach: 1) „wniosek/ki - demande, motion, conclusion, requête" (Łozińska-Małkiewicz 2003: 783); 2) „wniosek (prośba) - demande”, „wniosek (propozycja) - proposition, requête, motion” (Bem, Gebler 2011: 289); 3) „wniosek - motion, demande, dénonciation, requête" (Machowska 2013: 553). Tylko jeden słownik uwzględnia kolokację "osoba uprawniona", podając jako jej francuskie odpowiedniki „personne intéressée, ayant droit, personne autorisée” (Łozińska-Małkiewicz 2003: 376). W innym słowniku znajdziemy kolokację „osoba upoważniona do potwierdzania autentyczności dokumentów i podpisów - personne autorisée à confirmer l'authenticité des documents et des signatures" (Bem, Gebler 2011: 222), a w trzecim dwie kolejne kolokacje: „osoba upoważniona (do czegoś) - personne autorisée à (faire qqch)" i „osoba uprawniona do samodzielnego podejmowania decyzji - personne ayant un pouvoir de décision autonome" (Machowska 2013: 351). Poza tym wszystkie trzy słowniki odnotowują hasło „uprawniony”, proponując niewiele różniące się ekwiwalenty: 1) „titulaire d’un droit, ayant droit, autorisé” (Łozińska-Małkiewicz 2003:

15 „Wierzyciel” i „dłużnik” figurują jako strony zobowiązania w polskim, a „créancier” i „débiteur” we francuskim Kodeksie cywilnym. Natomiast terminy „uprawniony” i „zobowiązany” zostały użyte w polskich przepisach regulujących realizację obowiązku alimentacyjnego, gdzie oznaczają odpowiednio osobę uprawnioną i osobę obowiązaną do świadczeń alimentacyjnych, np. w Ustawie z dnia 7 września 2007 r. o pomocy osobom uprawnionym do alimentów, w Ustawie z dnia 25 lutego 1964 r. - Kodeks rodzinny i opiekuńczy. Przepisy te należą do aktualnych źródeł prawa rodzinnego, które czterema dekretami z lat 1945 i 1946 zostało wyodrębnione z aktów normatywnych prawa cywilnego (Strzebinczyk 2010: 21-24). We Francji obowiązek alimentacyjny reguluje francuski Kodeks cywilny. 
729); 2) „autorisé, titulaire, ayant droit” (Bem, Gebler 2011: 280); 3) „ayant-droit, titulaire d'un droit, habilité (habilitée)" (Machowska 2013: 616).

Widzimy więc, że przy użyciu środków językowych dostępnych w trzech słownikach wziętych tu pod uwagę przetłumaczenie kolokacji „wniosek osoby uprawnionej" przez tłumaczy nieznających społeczno-kulturowego kontekstu pisma przewodniego może przynieść różne efekty. Podobnie rzecz się ma w przypadku innych problemów tłumaczeniowych i tłumaczenia wykonywanego $\mathrm{w}$ toku innych postępowań. Wobec takiego stanu rzeczy odpowiednie teksty paralelne i inne zasoby językowe, dostępne na przykład na wymienionych powyżej stronach internetowych, jawią się już nie tylko jako skuteczne narzędzia pracy tłumacza, ale także jako publikacje o charakterze preskryptywnym ${ }^{16}$, przyczyniając się $\mathrm{w}$ ten sposób do zapewnienia odpowiedniej jakości tłumaczenia.

\section{Wnioski}

W przedmiocie egzekwowania obowiązku alimentacyjnego za granicą dwie różne wspólnoty kulturowo-językowe, Polska i Francja, przyjęły taki sam wzorzec postępowania. Jednakże terminologiczno-frazeologiczny wymiar tego wzorca nie znalazł dotąd odzwierciedlenia we współczesnych polsko-francuskich słownikach specjalistycznych. W związku z tym bardziej przydatne od tych ostatnich są $\mathrm{w}$ chwili obecnej te narzędzia pracy tłumacza, które umożliwiają dostęp do aktualnie używanych zasobów językowych z zakresu międzynarodowego obrotu prawnego, przede wszystkim wielojęzyczne akty prawne.

\section{Literatura}

Bem, M.T., Gebler, M., 2011, Słownik terminologii prawniczej francusko-polski polsko-francuski, Warszawa.

Ciszewski, J., 2010, Obrót prawny z zagranica w sprawach cywilnych $i$ karnych, Warszawa.

Cornu, M., 2011, „Terminologie et droit comparé dans le domaine de la culture", [w:] Droit de la traduction et traduction du droit, M. Cornu, M. Moreau (red.), Poitiers, s. 157-169.

Dunaj, B. (red.), 1996, Słownik współczesnego języka polskiego, Warszawa.

Gajda, S., 2004, „Język administracyjno-prawny w perspektywie językoznaw-

${ }^{16}$ O normie w tłumaczeniu zob. Solovà 2013. 
czej i prawoznawczej”, [w:] Język - Prawo - Społeczeństwo, E. Malinowska (red.), Opole, s. 19-31.

Jopek, A., 2001, „Relacja nadawczo-odbiorcza w polskim dyskursie prawnym i prawniczym w świetle pragmatyki komunikacyjnej”, [w:] Język $w$ komunikacji, G. Habrajska (red.), t. 3, Łódź, s. 82-97.

Karykowski, M., 2013, „Dialogisme interdiscursif en contexte judiciaire international", [w:] Romanica Wratislaviensia, E. Biardzka, J. Łukaszewicz (red.), nr 60: Altérités, contrastes, transferts, Wrocław, s. 35-44.

Łozińska-Małkiewicz, E., 2003, Polsko-francuski słownik terminologii prawniczej/Dictionnaire polonais-français des termes juridiques, Torun.

Machowska, A., 2013, Słownik terminologii prawniczej polsko-francuski/Dictionnaire de la terminologie juridique polonais-français, Warszawa.

Monjean-Decaudin, S., 2010, Approche juridique de la traduction du droit, www.tradonline.fr/.../sylvie-monjean-decaudin-traduction-juridique2010.pdf. (dostęp: 15 października 2011 r.).

Solovà, R., 2009, „Przekład tekstów skonwencjonalizowanych - wybrane problemy", [w:] Rocznik Przekładoznawczy, Toruń, t. 5, s. 201-211.

Solovà, R., 2013, Norma i praktyka w przekładzie tekstów skonwencjonalizowanych, Wrocław.

Strzebinczyk, J., 2010, Prawo rodzinne, Warszawa.

Wilkoń, A., 2002, Spójność i struktura tekstu. Wstęp do lingwistyki tekstu, Kraków.

Wojtak, M., 2004, Gatunki prasowe, Lublin.

Wojtak, M., 2005, „Genologia tekstów użytkowych”, [w:] Polonistyka w przebudowie, t. 1, Krakow, s. 132-148.

Zieliński, M., 2004, „Język administracyjno-prawny w perspektywie językoznawczej i prawoznawczej”, [w:] Język - Prawo - Społeczeństwo, E. Malinowska (red.), Opole, s. 9-18.

\section{Akty prawne}

Code civil, Tekst jednolity według stanu na dzień 1 września 2013 r. opublikowany przez Legifrance.gouv.fr - LE SERVICE PUBLIC DE LA DIFFUSION DU DROIT, http://www.legifrance.gouv.fr/affichCode.do?cidTexte=LEGITEXT000006070721. (dostęp: 29 października 2013 r.).

Decyzja Rady (WE) nr 941/2009 z dnia 30.11.2009 r. w sprawie zawarcia przez Wspólnotę Europejską Protokołu haskiego z dnia 23.11.2007 r. o prawie właściwym dla zobowiązań alimentacyjnych, Dz.Urz. UE L 331 z 16.12.2009.

Konwencja o dochodzeniu roszczeń alimentacyjnych za granicą sporządzona 
w Nowym Jorku dnia 20 czerwca 1956 r., Dz.U. z 1961 r. Nr 17, poz. 87, http://www.treaties.un.org. (wersja w języku francuskim; dostęp: 6 września 2012 r.).

Rozporządzenie Ministra Sprawiedliwości z dnia 28 stycznia 2002 r. w sprawie szczegółowych czynności sądów z zakresu międzynarodowego postępowania cywilnego oraz karnego w stosunkach międzynarodowych, Dz.U. z 2002 r. Nr 17, poz. 164 z późn. zm., http://isap.sejm.gov.pl/. (dostęp: 17 października 2013 r.).

Rozporządzenie Rady (WE) nr 44/2001 z dnia 22 grudnia 2000 r. w sprawie jurysdykcji i uznawania orzeczeń sądowych oraz ich wykonywania w sprawach cywilnych i handlowych, Dz.Urz. UE L 012 z 16.01.2001.

Rozporządzenie Rady (WE) nr 4/2009 z 18 grudnia 2008 r. w sprawie jurysdykcji, prawa właściwego, uznawania i wykonywania orzeczeń oraz współpracy w zakresie zobowiązań alimentacyjnych, Dz.Urz. UE L 131 z 18.05.2011.

Ustawa z dnia 23 kwietnia 1964 r. - Kodeks cywilny, Dz.U. Nr 16, poz. 93 $\mathrm{z}$ późn. $\mathrm{zm}$.

Ustawa z dnia 25 lutego 1964 r. - Kodeks rodzinny i opiekuńczy, Dz.U. Nr 9, poz. $59 \mathrm{z}$ późn. $z$ m.

Ustawa $\mathrm{z}$ dnia 7 września 2007 r. o pomocy osobom uprawnionym do alimentów, Dz.U. z 2009 r. Nr 1, poz. 7 z późn. zm.

\section{Polish-French translations in recovery of child support: bilingual dictionaries and parallel texts as translator's tools}

\section{Summary}

In the article the problem of certified translation performed in the course of recovery of maintenance abroad is discussed. Firstly, it presents the main characteristics of the object of translation, and then answers the question why parallel texts are nowadays a better tool for a translator as compared to Polish-French legal terminology dictionaries that are traditional in their form. The practice of certified translation shows that the terminological-phraseological dimension of maintenance claims enforcement adopted in Poland and in France still fails to be reflected in specialist dictionaries. Multilingual legal acts and other parallel texts, by contrast, allow the translator to have an access to current language resources in the field of international legal transactions.

Keywords: certified translation, maintenance claim, parallel texts

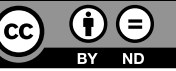

